\title{
REPRODUCTION CYCLE AND TOLERANCE TO TEMPERATURE AND SALINITY OF AMYLOODINIUM OCELLATUM (BROWN, 1931) (DINOFLAGELLIDA).
}

\author{
I. PAPERNA*
}

\begin{abstract}
SUMMARY. Reproduction cycle and tolerance to temperature and salinity of Amyloodinium ocellatum (Brown, 1931) (Dinoflagellida) was investigated in the laboratory using postlarval Sparus aurata (L.) as fish host and by in vitro study of the parasite is reproductive stage. Trophont growth was linear by length and exponential by volume, continuous to detachement stage at the size of $50-90 \mu \mathrm{m}$ in length. At $19-24^{\circ} \mathrm{C}$ detachment occurred gradually during the $3-5$ th days after settlement. At $16^{\circ} \mathrm{C}$ growth, as well as detachment, was delayed. However, by the 6-7th day trophonts still attached exceeded $100 \mu \mathrm{m}$ in length. When detached, trophonts of any age and size were transformed into dividing tomonts. 24 -hour old, $<25 \mu \mathrm{m}$ length trophonts, however, immediately sporulated with no division. The number of divisions to sporulation was related to the size at detachment. For reproduction, $18-30^{\circ} \mathrm{C}$ was the optimal temperature range, although the minimal division time was at $23-27^{\circ} \mathrm{C}$. Divisions were delayed and sporulation was interrupted at $15^{\circ} \mathrm{C}$. Complete interruption of division and gradual mortality occurred at $8^{\circ} \mathrm{C}$. At $35^{\circ} \mathrm{C}$ the reproduction process of the tomonts was severely damaged. Tolerance to salinity was dependent on ambient temperature and was the widest at $24-25^{\circ} \mathrm{C}$. Divisions occurred between 1-78 ppt, but uninterrupted division, full yield sporulation and effective infection of fish occurred only between 10 to $60 \mathrm{ppt}$. No division occurred above $80 \mathrm{ppt}$, however, short term incubation up to 4 days in salinities up to $180 \mathrm{ppt}$ did not affect division potency. Wide variation in tolerance was, however, evident between tested population as well as individual tomont in each population.
\end{abstract}

\section{Le cycle de reproduction et la tolérance à la température et à la salinité de Amyloodinium ocellatum (Brown, 1931) (Dinoflagellida)}

RÉSUMÉ. Le cycle de reproduction et la tolérance à la température et à la salinité de Amyloodinium ocellatum (Brown. 1931) (Dinoflagellida) ont été étudiés en laboratoire, en utilisant des alevins de Sparus aurata (L.) comme hòte, et par une étude in vitro de l'état reproductif du parasite. La croissance des trophontes est linéaire en longueur et exponentielle en volume, et ce, jusqu'au détachement du parasite, à la taille de $50-90 \mu \mathrm{m}$. A la température de $19-24^{\circ} \mathrm{C}$, le détachement survient graduellement entre le $3^{\mathrm{e}}$ et $5^{\mathrm{e}}$ jour après l'attachement. A $16^{\circ} \mathrm{C}$, la croissance, comme le détachement, est retardée. Cependant, durant le $6^{\mathrm{e}}$ ou $7^{\mathrm{e}}$ jour, les trophontes encore attachés dépassent $100 \mu \mathrm{m}$ de longueur. Détachés, les trophontes de tout âge et de toute taille se transforment en tomontes en division. Cependant, les trophontes âgés de $24 \mathrm{~h}$ et de moins de $25 \mu \mathrm{m}$ de long sporulent immédiatement et ce sans division. Le nombre de divisions, jusqu'à la sporulation,

* The H. Steinitz Marine Biolgy Laboratory of The Hebrew University of Jerusalem, Eilat, Israel. Accepté le I 8 mai 1983 . 
est en relation directe avec la taille du parasite au détachement. En ce qui concerne la reproduction, la température optimale se situe entre $18-30^{\circ} \mathrm{C}$, bien que le temps minimal de division soit entre $23-27^{\circ} \mathrm{C}$. Les divisions sont retardées, et la sporulation interrompue à $15^{\circ} \mathrm{C}$. Une complète interruption de la division, et une graduelle mortalité, surviennent à la température de $8^{\circ} \mathrm{C}$. A $35^{\circ} \mathrm{C}$ le processus de reproduction des tomontes est profondément altéré. La tolérance à la salinité dépend de la température ambiante et est la plus large à $24-25^{\circ} \mathrm{C}$. Les divisions surviennent entre 1 et $78 \mathrm{ppt}$, mais une division continue, une sporulation optimale et une infection effective des poissons apparaissent seulement entre 10 et $60 \mathrm{ppt}$. Il n'y a aucune division au-dessus de $80 \mathrm{ppt}$; cependant des incubations à court terme de 4 jours, dans une salinité de $180 \mathrm{ppt}$, n'ont aucun effet sur le potentiel de division. Une large variation dans la tolérance apparaît entre les populations étudiées ainsi qu'entre les individus tomontes de chaque population.

\section{Introduction}

Since 1977, repeated outbreaks of infestation by Amyloodinium ocellatum (Brown, 1931) with resulting mortalities, occurred in gilthead sea bream (Sparus aurata), cultured in Eilat by the Mariculture Laboratory of the Israel Oceanographic Limnological Research Ltd. Infestations affected larvae and postlarvae in the hatchery as well as large fish in ponds and rearing tanks. Epizootological data as well as descriptions of the pathological and histopathological changes induced by A. ocellatum in the cultured fish in Eilat were reported in a preceeding communication (Paperna, 1980).

Data on the parasite biology, reproduction and tolerance to environmental parameters is the subject of the present communication.

The detailed studies of Brown, 1934 ; Nigrelli, 1936 ; Brown \& Hovasse, 1945 on the parasite morphology and reproductive cycle have not been followed up since then by any further comprehensive studies on this parasite, which is one of the most troublesome pests of marine fish in captivity. Some data on the parasite response to temperature, and its tolerance to salivity are available in the above cited publications. Additional data were presented more recently in a short communication by Cheung, Ruggieri and Nigrelli (1978).

Terminology of the different developmental stages of $A$. ocellatum follows that of Chatton's for parasitic dinoflagellates, adopted by Brown and Hovasse (1945) for A. ocellatum namely : trophont, for the parasitic stage; tomont, for the dividing stage ; tomite, for the daughter cells of the tomont and dinospore for the free living infective stage.

\section{Material and methods}

At the early phase of the study (during 1978), parasites for experiments were obtained from gills of infected fish, subsequently (during 1979, 1980) postlarvae (12-18 mm in length), where infection occurs predominantly on the skin, were found 
to be more suitable for in situ observations as well as being a better source for parasites for in vitro studies. Further standardization of the experimental procedures was obtained by inducing simultaneous infections to the fish, which ensures a uniform age of the parasites under study.

Simultaneous infection was obtained by exposing postlarvae to 1-3 hours to active dinospores and then returned to clean dishes. Fed on artemia nauplii postlarvae could be mainteinaed for up to one week in small 6-9 $\mathrm{cm}^{3}$ dishes in aerated seawater. Postlarvae also survived for several hours (even over a day) in petri dishes ( 5 or $8 \mathrm{~cm}$, diam). which enabled both in situ observations and quantitative follow up of the infection.

In vitro experiments: Trophonts from the skin were removed from heavily infested postlarvae, with a fine hairbrush, into sterile, disposable $48 \mathrm{~mm}$ diam. plastic petri dishes. Transfer was either directly into the selected experimental conditions (of temperature and salinity) or following a prior acclimation of $1-2$ hours in $20^{\circ} \mathrm{C}$ sea water $(40 \mathrm{ppt})$ before transfer to the selected conditions. Incubated tomonts were examined daily using an inverted microscope and the number of divisions per tomont were recorded up to 3 days after dinospore release. Hyposaline concentrations were obtained by dilutions of Red Sea water $(40 \pm 1 \mathrm{ppt})$ with distilled water. Final desired salinities were adjusted by checks using an optic refractometer (A/O cat. No. 10419). Hypersaline concentrations were obtained by dilution of a stock solution of 100 ppt, prepared either from dry salt extracted from Red Sea water by evaporation or by concentration of water through freezing. From counts of tomont divisions, mean number $(\bar{x}), \pm$ standard deviations (SD) of tomits per tomont $(t / T)$ and number of divisions $(n)$ were calculated. Coefficient of variation ${ }^{1}$ was employed as measure for degree of discrepancy from the synchrony in the sequence of division among tomonts. Regression analysis was employed in the study of trophont growth pattern, it has been also employed to express tomont division process in time. However it could not be applied for all incubation condition combinations and was abandoned in favor of direct presentation of the obtained data.

\section{Results}

\section{1- Growth of the trophont and the span of the parasitic phase}

Trophonts developing from the $12-15 \mu \mathrm{m}$ diameter dinospores attached to fish maintained at $19-24^{\circ} \mathrm{C}$, reach the size of $85-100 \times 56-99 \mu \mathrm{m}$ within 4-5 days. At this age trophonts detach and transform to tomonts. The growth process appears to be continuous from attachment to detachment. Change in trophont length (long axis) as well as width (short axis) over a period of time (in hours) were best fit with linear

x. $C=\frac{\text { IOOSD }}{x}$ 
regression (when compared with exponential and power curves) with a correlation coefficient of $0.954(n=71)$ for length and 0.956 for width. Moreover the $Y_{o}$ values obtained from the regression equation $\mathrm{Y}_{\mathrm{t}}=\mathrm{Y}_{\mathrm{o}}+\mathrm{bt}$, for length and width, $11.86 \mu \mathrm{m}$ and $4.81 \mu \mathrm{m}$ respectively, approximated the diameter and "height" of the attaching dinospore, e.g. 12-15 and 4-5 m respectively. Regression coefficients for length and width were almost identical, 0.719 and 0.725 respectively, evidencing isometry between growth in length and width ( fig. 1). This isometry in growth was also evident when changes by volumes were regressed vs. time. Growth by volume, extrapolated from trophont length and width from the equation $3 / 4 \pi(\mathrm{L}+\mathrm{W} / 4)^{3}$ for calculating ovoid-sphere volume, was best fit to power curve with a regression coefficient b approximating 2.5 (in the equation $\mathrm{Y}_{\mathrm{t}}=2.79 \mathrm{t}^{2.49}$ ) and a correlation coefficient of 0.97 ( $n=71)$ (fig. 2).

On subsequent experiments under apparently similar conditions with the same fish and parasite stocks, some variability was evident in the obtained coefficients of regression $(0.63-0.82)$; this appeared to correspond with the variations in the maximum size the trophonts reached before detachment.

Slower growth was evident in trophonts attached to fish kept at $16^{\circ} \mathrm{C}$, but they retained their linear (additive) growth pattern. Exposure of fish to dinospores at $16^{\circ} \mathrm{C}$ failed to yield suitable infection level for a followup, apparently due to the suppressed activity of the dinospores at such temperature. Moreover, short term exposures were not effective due to the limited supply of dinospores at that stage of the study (1982). Therefore fish were exposed to infection for 24 hours at $24^{\circ} \mathrm{C}$ and after an additional 24 hours, when infection success was verified, infected fish were transferred to $16^{\circ} \mathrm{C}$. The prolonged exposure to infection resulted in the appearance of three distinct sized cohorts of trophonts. Before calculating the regression curves,

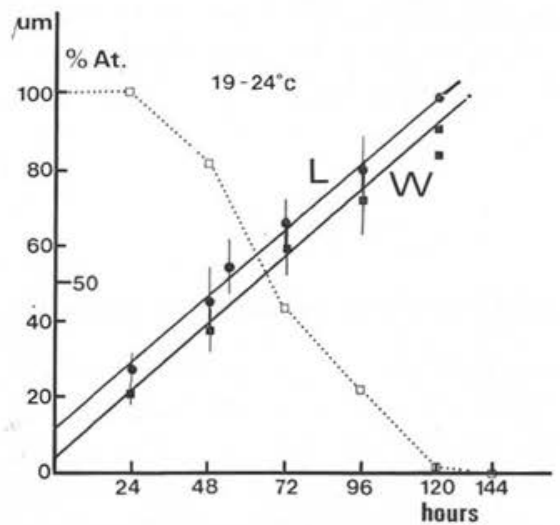

FIG. I. - Linear regression lines of growth in length (L) and width (W) (in $\mu \mathrm{m}$ ) vs. time (in hours) and detachment process curve (expressed as \% remaining attached [A \%] vs. time) of trophonts infecting skin of gilthead sea postlarvae incubated at $19-24^{\circ} \mathrm{C}$. Regression equations for length and width are $\mathrm{Y}=\mathrm{II} .86+0.72 \mathrm{t}$ and $\mathrm{Y}=4.8 \mathrm{I}+0.72 \mathrm{t}$, respectively $(n=7 \mathrm{I})$. 


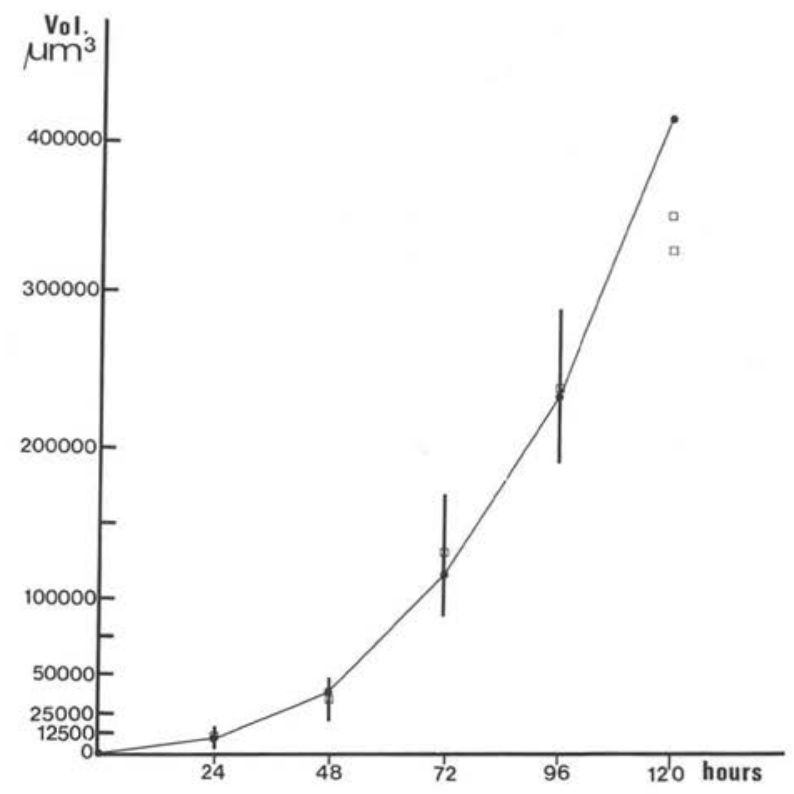

FIG. 2. - Growth in volume $\left(\right.$ Vol. $\left.\mu \mathrm{m}^{3}\right)$ of trophonts infecting skin of gilthead seabream postlarvae incubated at $19-24^{\circ} \mathrm{C}-$ exponential regression line of volume vs. time in hours $\mathrm{Y}=2.79^{\mathrm{t} \cdot 49}(n=7 \mathrm{I})$.

age discrepancies between the cohorts were estimated by extrapolation from growth curves of trophonts at $19-24^{\circ} \mathrm{C}$ and incorporated into the calculation. Growth curves conformed to the linear pattern $(\mathrm{r}=0.93-0.97)$ and the obtained regression coefficients were considerably lower than those of the trophont growth curves at $19-24^{\circ} \mathrm{C}$ (fig. 3). However, coefficients progressively declined from the larger to the medium and smaller sized cohorts, e.g., $0,47,0.35,0.22$, respectively, thus suggesting either discrepancies in growth rates among the tomonts, or bias due to differences among the cohorts in incubation time at $19-24^{\circ} \mathrm{C}$ in the early stage of growth. Obtained $\mathrm{Y}_{\mathrm{o}}$ were also apparently biased by the accelerated early growth phase at elevated temperatures, thus being somewhat higher (17.47-19.99) that the known size of the attaching dinospore. Cohort size, but on a less pronounced scale was also evident among trophonts developing in $19-24^{\circ} \mathrm{C}$ on fish exposed to 3 hours infection.

The process of detachment of trophonts is gradual. Detachment of some trophonts was evident even in the earlier stages of the parasitic phase, particularly when the infection load was high. In fish maintained at 19-240 $\mathrm{C}$, the number of detaching trophonts increased from the 3rd day onward and even on the 4th day only a small fraction of the trophonts remained attached (less than $25 \%$ ), only on rare occasions did a few trophonts remain on the fish beyond the 5 th day and none beyond the 6th day (fig. 1). Thus the majority of the trophonts detached from the fish 
before reaching the maximum potential size of $100 \times 93-99 \mu \mathrm{m}$. Therefore, the common sizes of the trophonts detached from skin of larval fish, as well as from gills of large fish, ranged from $80 \times 56$ to $88 \times 80 \mu \mathrm{m}$, while the largest specimens, approaching $100 \mu \mathrm{m}$ in diameter, were only occasionally found.

Slowdown of trophont's growth at low temperature $\left(16^{\circ} \mathrm{C}\right)$ was caused by delay in detachment from the fish. Trophonts reached their maximum size of about $100 \mu \mathrm{m}$ in length only after 132-138 hours of attachment and by then a large number of these trophont still remained attached to the fish $(f i g .3)^{2}$. Moreover a fair number of trophonts $(20-50 \%)$ exceeded the size of $100 \mu \mathrm{m}$ in length (or diameter) before they were detaching.

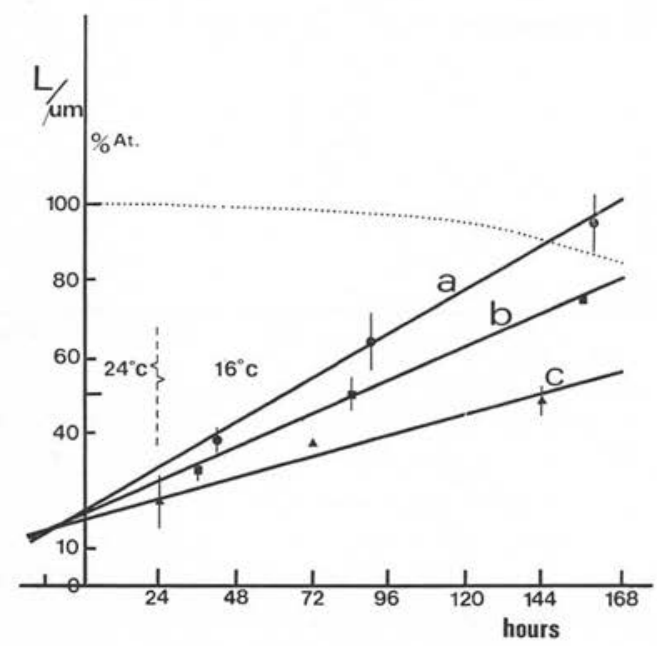

FIG. 3. - Growth, in length and detachment (as \% remaining attached [A \%]) of trophonts infecting skin of gilthead seabream postlarvae incubated at $16^{\circ} \mathrm{C}$ (Ist 24 hours at $24^{\circ} \mathrm{C}$ ). Regression line of length vs. time of three age cohorts $(\mathrm{a}, \mathrm{b}, \mathrm{c}): \mathrm{Y}_{\mathrm{a}}=\mathrm{r} 9.99+0.47 \mathrm{t}, n=34$, $\mathrm{r}=0.96 ; \mathrm{Y}_{\mathrm{b}}=\mathrm{I} 9.49+0.35 \mathrm{t}, n=4 \mathrm{I}, \mathrm{r}=0.97 ; \mathrm{Y}_{\mathrm{c}}=17.47+0.22 \mathrm{t}, n=\mathrm{I0}, \mathrm{r}=0.93$.

\section{2 - Pattern of tomont divisions}

Onset of division was evident in the detached parasite within 3-6 hours ${ }^{3}$, following retraction of the rhizoids, closing of the opening in capsule and formation of a solid body wall (encapsulation ?). Tomites divided by accurate binary fission and the sequence of divisions under optimal conditions (defined further) was constant, every 9-12 hours to the final division. Divisions occurred in a completely synchronized pattern in all the tomites within the tomont. Thus, at any given stage in this process,

2. Complete detachment occurs apparently only after 6 or 7 days, however fish failed to survive to this time.

3. In some instances onset of division was delayed as much as 24 hours. 
the tomont contained $2^{n}$ tomites of equal size. By the final division each tomite differentiated and transformed into two dinospores which escape from the tomite capsule ( fig. 4). Occasionally dinospores escaped from the tomite while still attached to each other and final separation occurred outside the mother cell. This final process in which tomites differentiated into dinospores and the latter were relased, will be referred to in the text as " sporulation " stage. Incubation time from detachment to sporulation was determined by the number of divisions which occurred in the tomont and the time lapse between divisions. The latter was temperature dependent and was also prolonged by adverse ambient conditions (see vide).

Contrary to the accurate synchronization of divisions within each tomont, sequences of divisions among the dividing tomonts were less synchronized, with resulting variability in sporulation time among the tomonts ( $f$ g. 5). Variability in time lapse before initial division and, subsequently, in the sequences of divisions, could not be eliminated even when detachment time was strictly standardized. Even under such controlled conditions "spreading phenomenon" of dinospore release usually extended over a period of 24 hours and could extend to 48-72 hours when incubated at the lower range of the optimum temperature $\left(18-20^{\circ} \mathrm{C}\right.$, see vide) or at adverse ambient conditions.

\section{3 - Reproductive potential of detached trophonts as related to age and size}

The reproduction potential of the tomont, i.e., number of divisions before "sporulation" was determined by trophont size at detachment. Since tomont growth rate was continuous, reproductive potential of the tomont could be further correlated with trophont age. However where delay in growth rate was evident (if maintained at low temperature), the ultimate size of the trophont, rather than its actual age, determined the number of divisions in the tomont.

Trophonts 20-25 $\mu \mathrm{m}$ long, detached during the first 24 hours of their parasitic life failed to divide, they sporulated and within 24 hours of incubation yielded two active swimming dinospores ( $f$ ig. 4). Division capacity was already evident in 30$35 \mu \mathrm{m}$ trophonts (detached after 30-48 hours). Tomonts obtained from these trophonts sporulated after 1-3 divisions ( fig. 6). Tomonts obtained from 38-40 $\mu \mathrm{m}$ long trophonts sporulated after 3-4 divisions and those obtained from 46-55 $\mu \mathrm{m}$ trophonts sporulated after 4-5 divisions. Tomonts obtained from trophonts larger than $60 \mu \mathrm{m}$ (detached after 72-96 hours) divided 5-6 times before sporulation which is the normal maximum division capacity of the tomonts ( $f$ ig. 5). Seven divisions were only exceptionally obtained in a few tomonts obtained from 95-100 $\mu \mathrm{m}$ long trophonts (detached after 96-120 hours) ( fig. 7, 8). Time lapse between divisions was not affected by the initial size of the tomont, while considerable variability in the number of divisions before sporulation was evident even among tomonts of the same size and age classes ; part of the tomonts sporulated before exerting their full division capacity as expected from their size. Since the number of divisions affected the time of sporulation, this discrepancy in division number to sporulation further contributed to the "spread phenomenon" of dinospore release over time. 


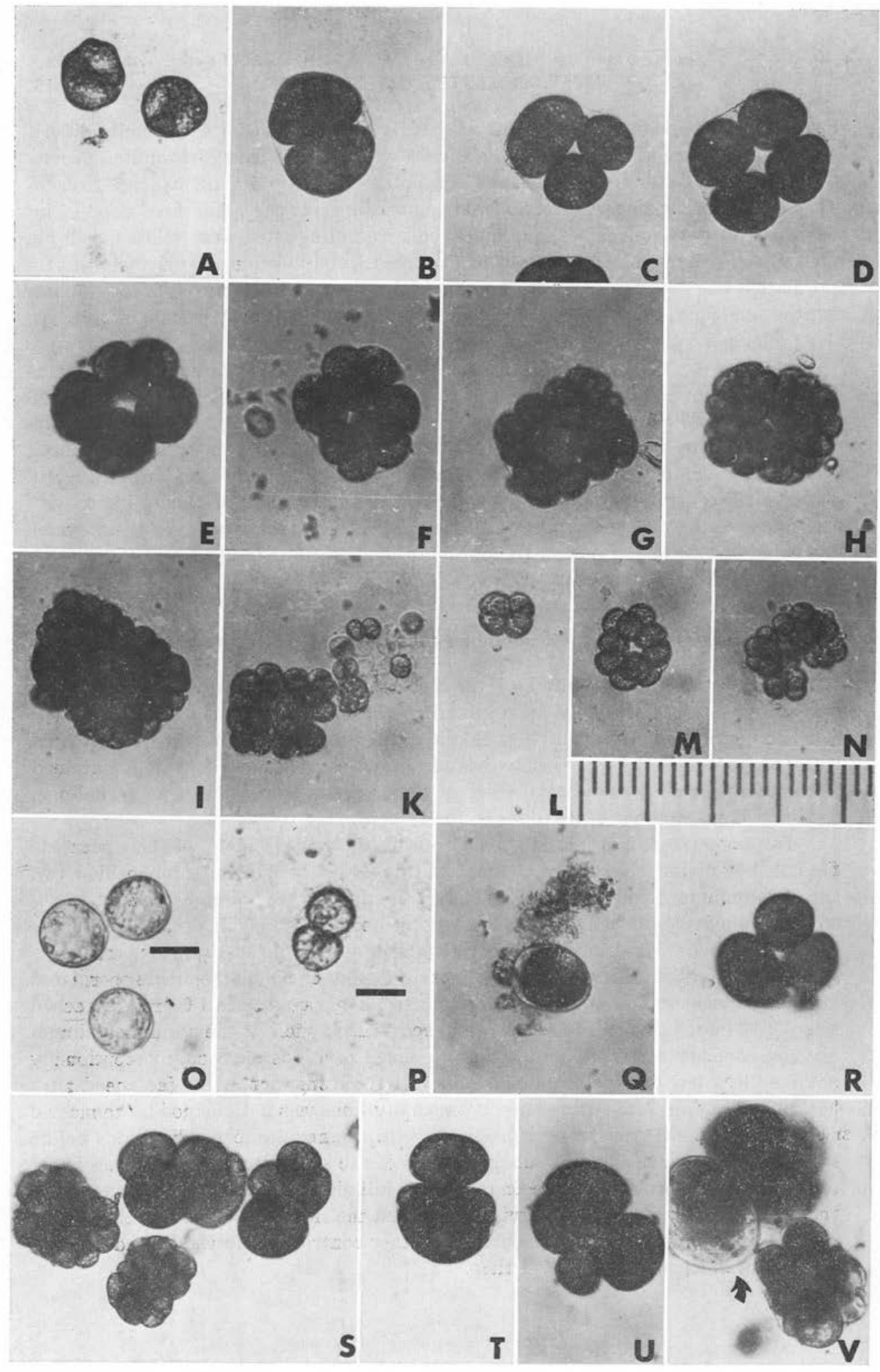




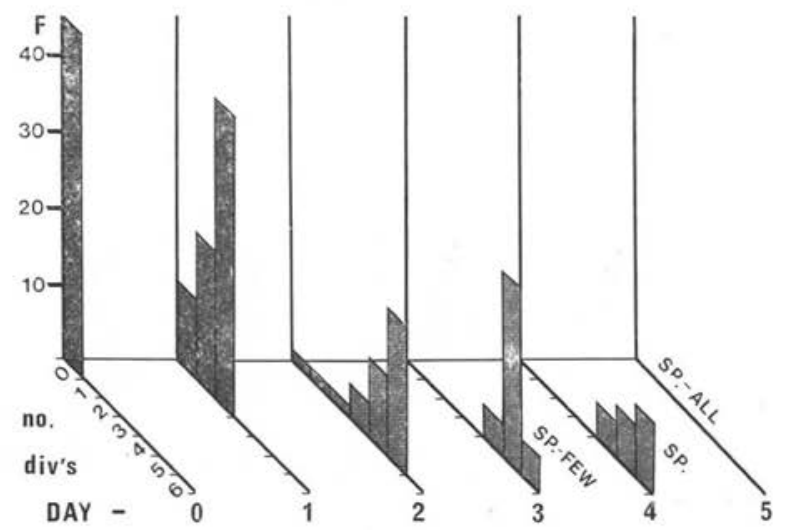

FIG. 5. - Sequences of divisions in tomonts (at $20^{\circ} \mathrm{C}, 40 \mathrm{ppt}$ salinity) obtained from $6 \mathrm{I}-8 \mathrm{o} \mu \mathrm{m}$ long trophonts ( 96 hours old). F - frequency, no. div's - number divisions, SP — sporulation stage.

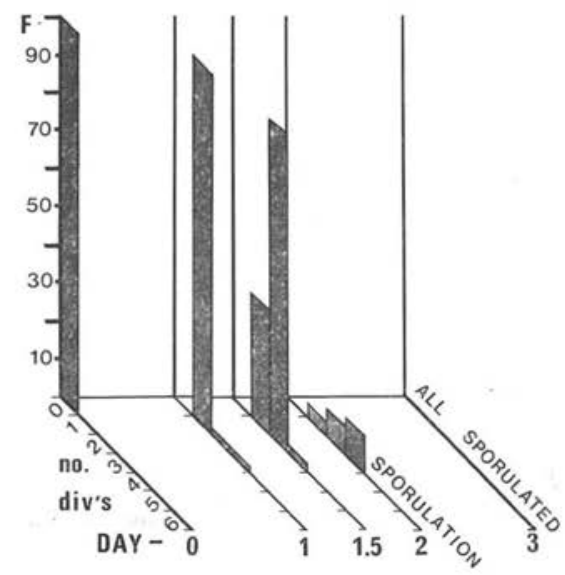

FIG. 6. - Sequence of division in tomonts (at $20^{\circ} \mathrm{C}, 40 \mathrm{ppt}$ salinity) obtained from $30-39 \mu \mathrm{m}$ long trophonts (30 hours old). Abbrev. as in fig. 5 .

FIG. 4. - A-K stages in division of a large tomont (ex. 96 hours old trophont) : A. onset of Ist division. B. end of Ist division. C. $2 \mathrm{~d}$ division. D. end of $2 \mathrm{~d}$ division. E. $3 \mathrm{~d}$ division. F. 4 th division. G. 5 th division. H. end 5 th division ( 32 tomites). I. end 6 th division ( 64 tomits). K. sporulation (after 5 th division). L-N. division of small tomont (ex. $4^{8}$ hours old trophont). L. end of $2 \mathrm{~d}$ division. M. onset of 4 th division (ro tomits). N. onset of sporulation after 5 th division. O. free dinospores (scale $9 \mu \mathrm{m}$ ). P. sporulation of 24 hours detached trophont (scale $16 \mu \mathrm{m})$. Q. encapsulated non-dividing tomont on incubation at $80 \mathrm{ppt}$ salinity. R-V. deformed tomonts due to loss of division synchrony and death of individual tomites : R.U.V. following incubation at 4-8 ppt. S, T. following incubation at $63 \mathrm{ppt}$. V. arrow - undivided hydropic tomont. Scale for $\mathrm{A}-\mathrm{N}$ and $\mathrm{Q}-\mathrm{V}$ below $\mathrm{M}, \mathrm{N}$; each unit ro $\mu \mathrm{m}$. 


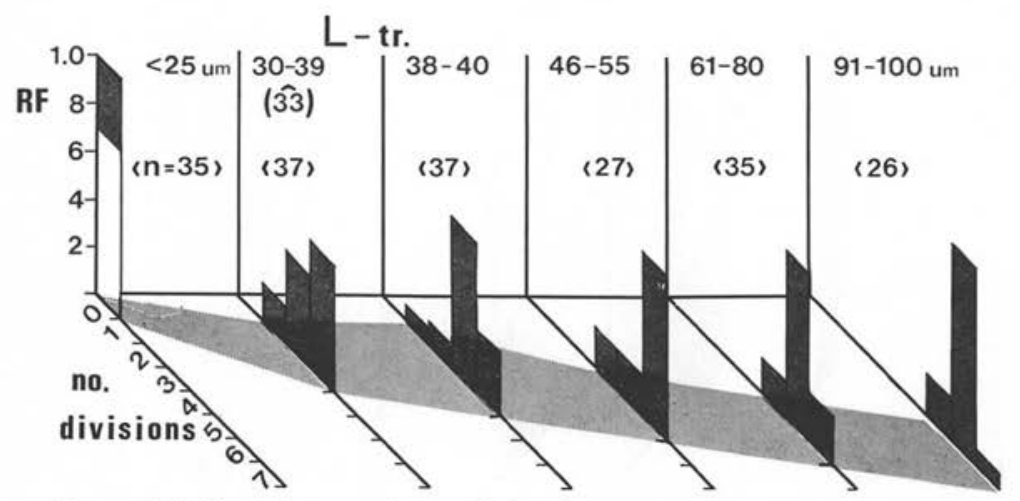

FIG. 7. - Stage of division at onset of sporulation in groups of tomonts obtained from different size trophonts. (Only part of the $<25 \mu \mathrm{m}$ group sporulated [darkened area]). RF - Relative frequency, L-tr. - trophont length.

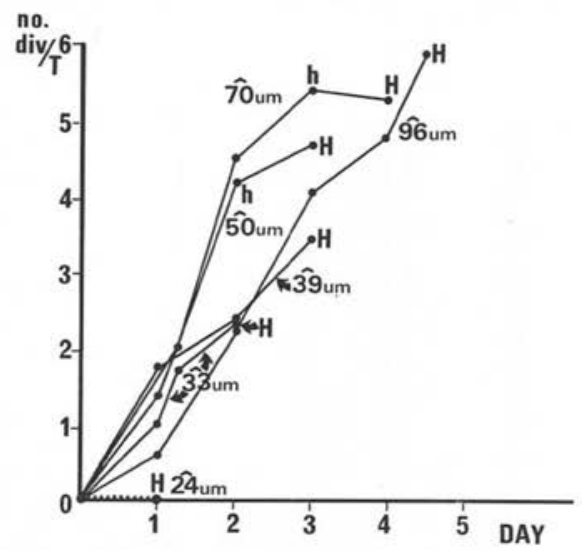

FIG. 8. - Differences in sequence of division (no. div/T : mean no. of divisions per tomonts) vs' time, in days (in $20^{\circ} \mathrm{C}$ and $40 \mathrm{ppt}$ ) between tomonts obtained from different size trophonts (given as means of the group). $\mathrm{H} / \mathrm{h}$ - sporulation, complete or partial.

\section{4- Effect of temperature on tomit division and sporulation (Table I)}

Temperatures of $18-30^{\circ} \mathrm{C}$ can be defined as the optimum range for tomont division and sporulation. At the mid-optimum range of $23-27^{\circ} \mathrm{C}$, tomit reproduction was most efficient, 2-3 days to sporulation with "division success" 4 of $100 \%$. Tomonts usually divided to their maximal division capacity, divisions were synchronic, conforming well to the $2^{\mathrm{n}}$ pattern and occurring every 9-10 hours. At the upper optimum limit, $29-30^{\circ} \mathrm{C}$, a decline in the number of divisions was evident, and in some instances final divisions and sporulation were delayed and terminated only on the 4 th day ( fig. 11). In the lower optimum range of $18-20^{\circ} \mathrm{C}$, there was a slow-

4. $\%$ of the studied tomites which divided and sporulated. 
AMYLOODINIUM OCELLATUM

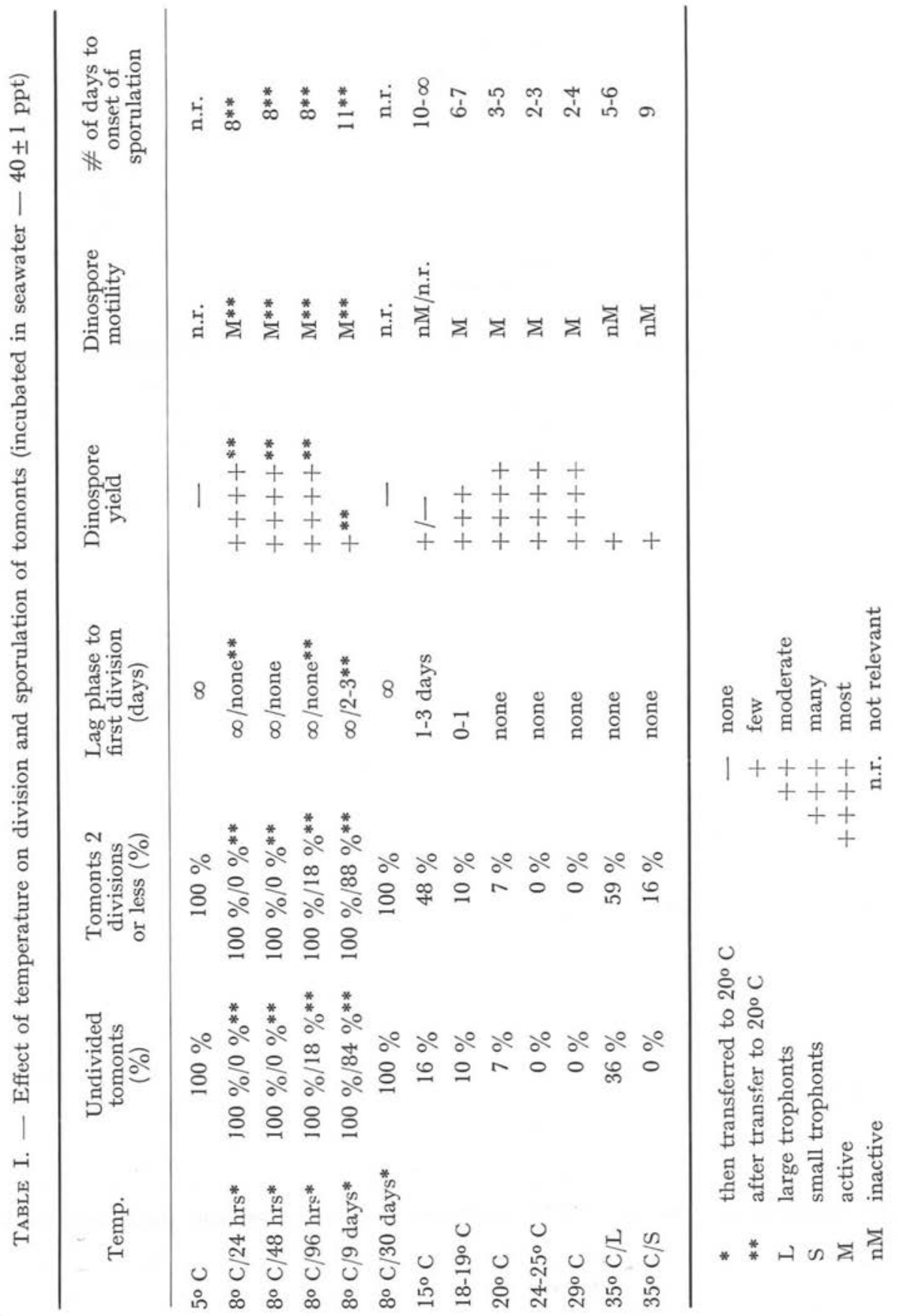


down in division sequence (division per 19-34 hours) and a decline in division success (to $93-80 \%$ ). At $18^{\circ} \mathrm{C}$ (and occasionally even at $20^{\circ} \mathrm{C}$ ) however, tomits appeared to exert their upmost division potential, their number of divisions before sporulation was the highest, compared to those incubated at the higher temperatures (fig. 9). At $15^{\circ} \mathrm{C}$, there was already a marked inhibition of the reproductive process. Transformation of detached trophonts to dividing tomonts was often delayed and first division occurred only after 24-72 hours. The division process was slow (division per 58-130 hours) and the time lapse between divisions also progressively increased with subsequent divisions to an almost complete cessation of reproduction after 3-4 divisions. Very few tomonts sporulated (after 10-16 days of incubation) with a yield of few dinospores. Recovery of the reproductive process and sporulation occured on return of incubation conditions to the optimal range $\left(20-25^{\circ} \mathrm{C}\right)$ even after 27 days of maintenance in $15^{\circ} \mathrm{C}$. However recovery was not complete and the rate of sporulation and dinospore yield failed beyond the optimum level. In two instances, an increase of ambient temperature to $20^{\circ} \mathrm{C}$ stimulated immediate sporulation of all incubated tomits irrespective of their state of division.

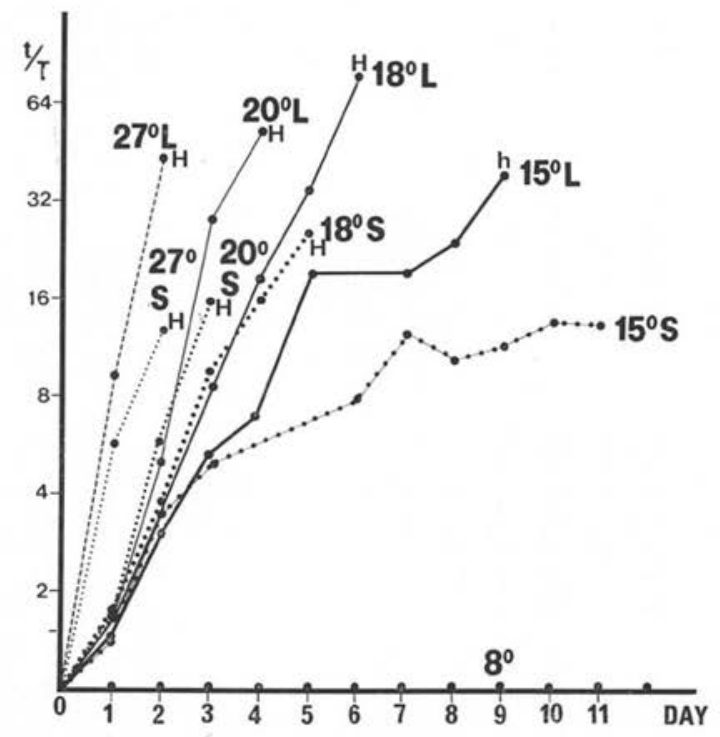

FIG. 9. - Effect of temperatures (at $40 \mathrm{ppt}$ ) on the process of tomont division : $t / \mathrm{T}$ mean number of tomites per tomont, $\mathrm{L}-$ large size tomonts, $\mathrm{S}-$ small size tomonts. $\mathrm{H} / \mathrm{h}-\mathrm{sporulation}$, complete or partial.

The process of division was totally inhibited during incubation at $8^{\circ} \mathrm{C}$. Detached trophonts were transformed into encapsulated tomonts but failed to divide. Return to optimal incubation temperature (of $20^{\circ} \mathrm{C}$ ) within 24-96 hours resulted in recovery of the division process. Sequences of division were delayed progressively as the incubation was prolonged. (From 24 to 32 hours per division, compared with 22 hours per 
division in the control group at $20^{\circ} \mathrm{C}$.) In groups of tomonts incubated for 48-96 hours there was also a slight decrease in division capacity. Incubation at $8^{\circ} \mathrm{C}$ for 7-9 days adversely affected the tomonts. On return to $20^{\circ} \mathrm{C}$, a lag phase of 2-3 days occurred before divisions were resumed, only $16 \%$ of the tomont resumed division and only a few completed their course of divisions and sporulated with a very poor overall yield of dinospores ( fig. 10).

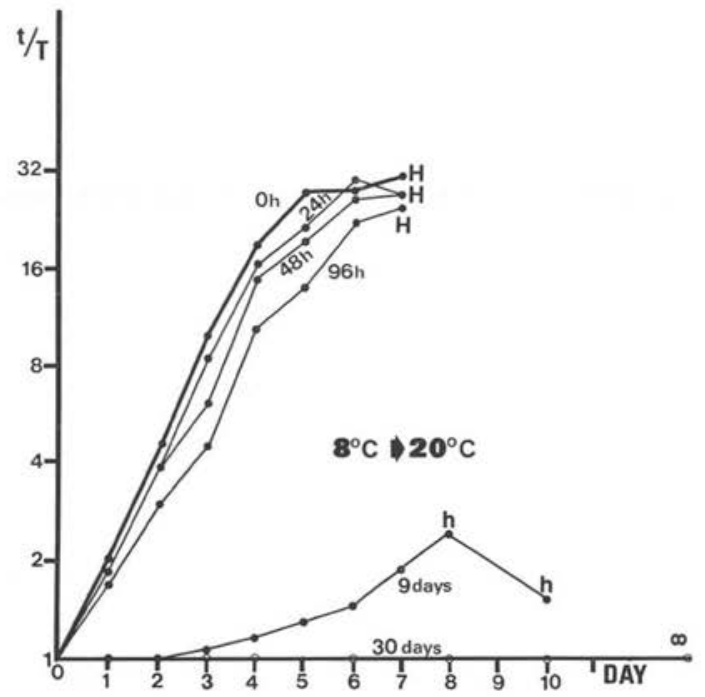

FIG. 10. - Effect of incubation in $8^{\circ} \mathrm{C}$ (at $40 \mathrm{ppt}$ ) (for 0-96 hours and 9-30 days) on tomonts division ability on transfer to $20^{\circ} \mathrm{C}$. $\mathrm{t} / \mathrm{T}$ - mean number tomites per tomont. $\mathrm{H} / \mathrm{h}-\mathrm{sporu}-$ lation maximal/low.

No divisions occurred in tomonts returned to $20^{\circ} \mathrm{C}$ after incubation for 30 days in $8^{\circ} \mathrm{C}$ as well as in $5^{\circ} \mathrm{C}$ ( fig. 10).

Temperatures approaching $35^{\circ} \mathrm{C}$ were detrimental to the tomonts. The detrimental impact became apparent when tomonts completed their second or third division : the sequence of subsequent divisions was delayed or interrupted, synchrony of divisions among the tomonts ${ }^{5}$ and within the dividing was disrupted with clear departure from the $2^{\mathrm{n}}$ pattern. Further deformations within the tomont resulted from gradual death of individual tomites within the tomont and in some tomonts all tomites eventually died. Still, a few of the surviving tomites within tomonts eventually sporulated but yielded defective - non-motile dinospores ( fig. 11).

Initial tomont size before division affected their tolerance to extreme temperatures. At $15^{\circ} \mathrm{C}$ smaller tomonts were more susceptible to the effects of temperature and the delay in the pace of division was more evident than in the larger ones. At atures.

5. With coefficient of variability increase to $75-125$ compared with $<70$ in optimal temper- 
$35^{\circ} \mathrm{C}$ tomonts obtained from large trophonts appeared to be more susceptible than tomonts obtained from small trophonts, with a resulting lower rate of division success ( $59 \%$ vs. $16 \%$ in the "small" tomonts) and fewer divisions to sporulation. However, the "larger" tomonts sporulated earlier than the smaller ones (on the 5-6th day vs. the 9th) (fig. 9, 11).

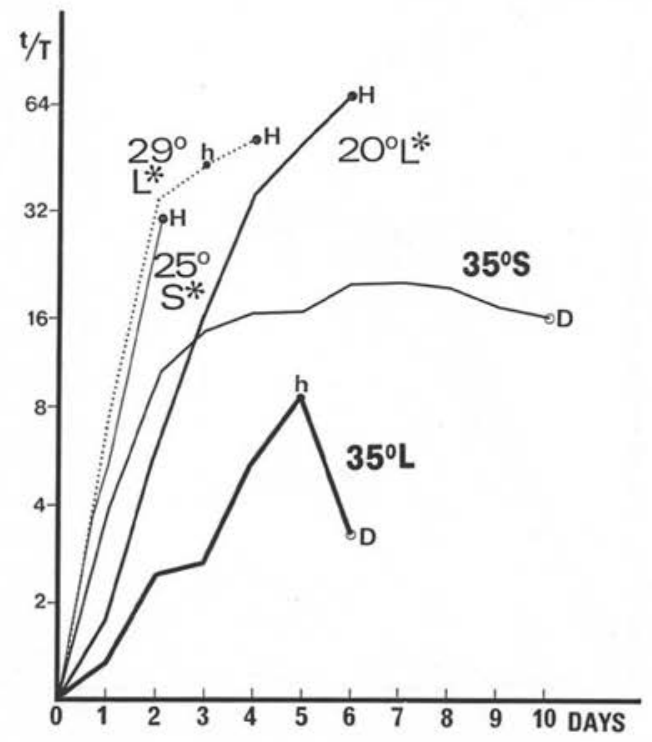

FIG. II. - Effect of high temperatures $\left(35^{\circ} \mathrm{C}\right)$ on tomonts division (at $40 \mathrm{ppt}$ ) $\left({ }^{*}\right.$ - different stock group, $35^{\circ} \mathrm{C}$ group same stock as that of fig. 10).

\section{5 - Effect of salinity on tomite division and sporalation}

Tolerance to salinity was dependent on the ambient temperature conditions (Tables $I I, I I I)$. Dividing tomonts demonstrated the widest tolerance range to salinity at $24-25^{\circ} \mathrm{C}$, tolerance to salinity narrowed as temperatures deviated from the mid-optimum range.

The adverse effect of extreme salinities resulted in (a). An increase in the number of tomonts which failed to divide, as well as a decrease in the number of tomonts which completed their course of division to sporulation (Tables II, III; fig. 12). (b) Increased delay in onset of divisions ("lag phase") (Tables $I I, I I I)$. (c) Slowdown in the sequence of divisions (e.g., increase in time lapse between divisions) ( $f g .13$ ), as well as an overall decline in the number of divisions to sporulation stage, which consequently caused a decline in the yield of dinospores per tomont ( fig. 14, 15, 16, 17). (d) Increase discrepancies in the sequences of division and number of division to sporulation among individual tomonts (fig. 18), with the result of an extreme "spreading effect" in the timing of sporulation among the tomonts. (e) Loss of syn- 
AMYLOODINIUM OCELLATUM

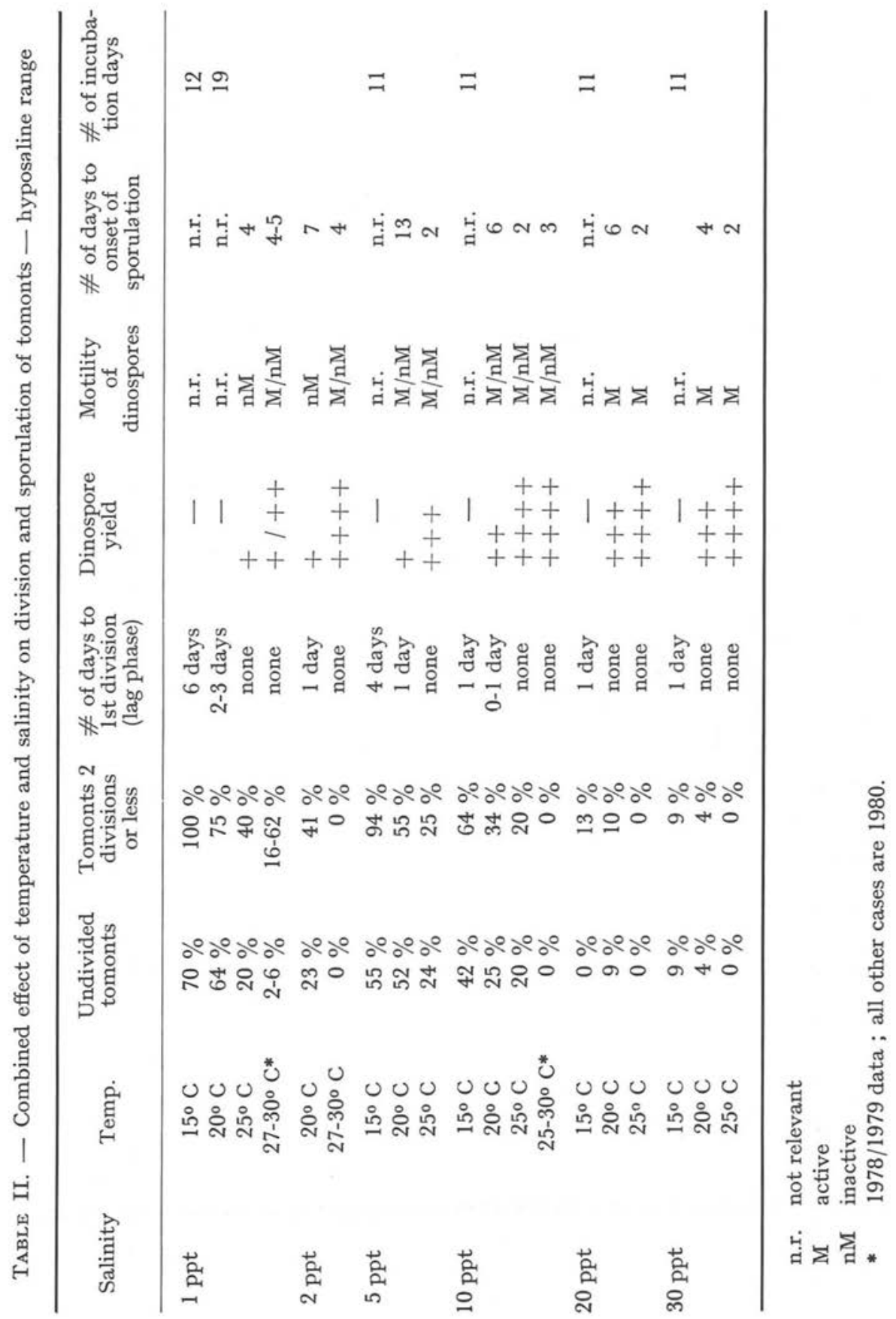




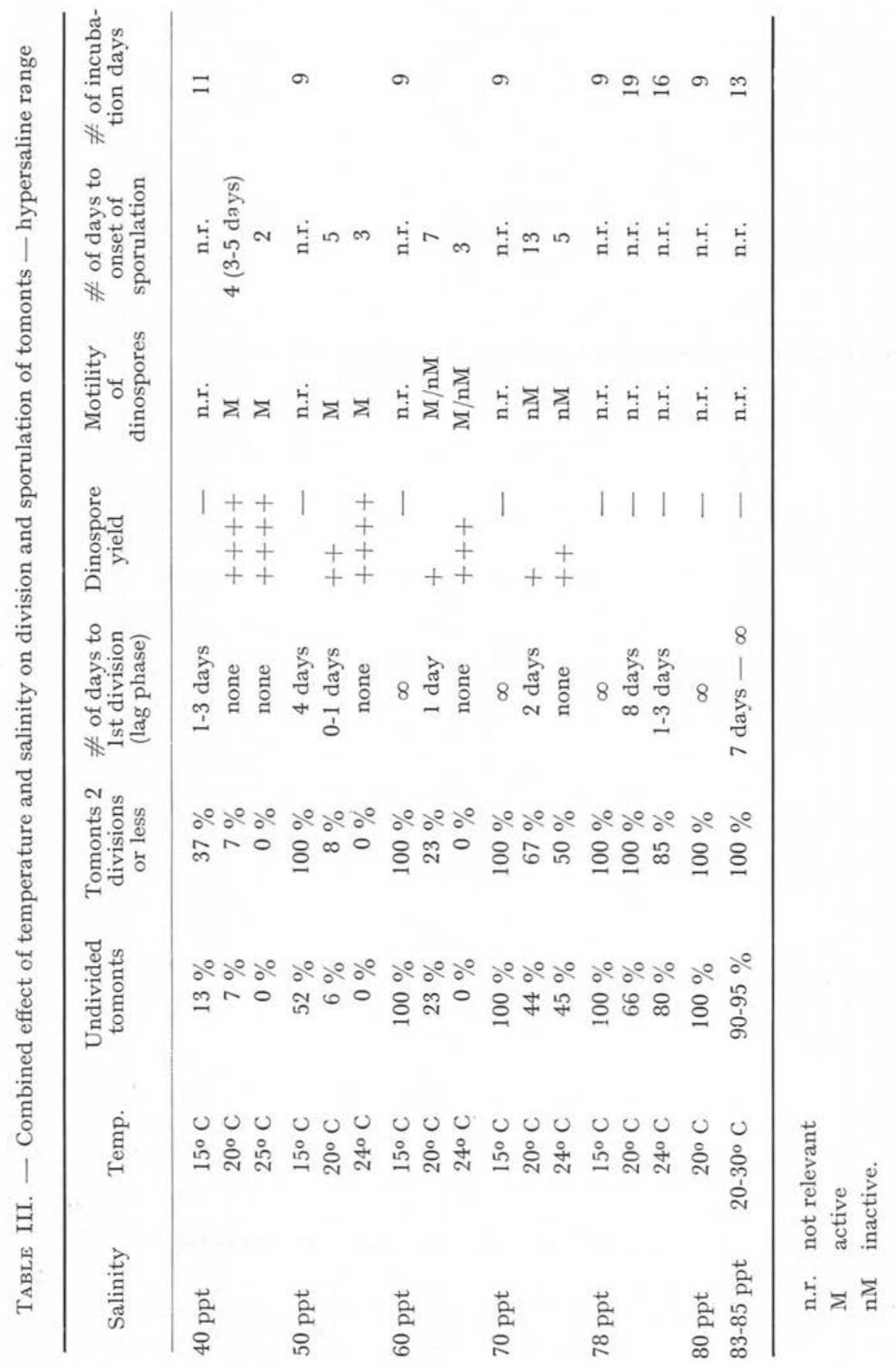


chrony of division within individual tomonts resulted in a departure from the $2^{\mathrm{n}}$ division pattern and in structural deformations ( fig. $4 \mathrm{R}-\mathrm{V}$ ). (f) Gradual death of individual tomites within the tomonts further disrupted the $2^{\mathrm{n}}$ division pattern and induced additional structural deformities.

At the hyposaline range, tomites within the tomont swelled, and became pale hydropic, vacuoles appeared and eventually individual tomits burst within the tomont. In hypersaline conditions the tomits became dense and dark, however, their cell did not collapse even at the extreme hypersaline conditions.

At $24-25^{\circ} \mathrm{C}$, no apparent damage to dividing and sporulating the yield of dinospores within the range of 10 to $60 \mathrm{ppt}$ was evident, although at the two extreme ends of this range, i.e., at 10 and $60 \mathrm{ppt}$, the motility and vitality of the dinospores declined. Some division activity, however, and even sporulation yielding a few dinospores occurred even in salinities as low as $0.5 \mathrm{ppt}$ and as high as $70 \mathrm{ppt}$. The few formed dinospores, however, lost their motility as soon as they emerged from the tomont. Some division activity occurred at $78 \mathrm{ppt}$, but division never proceeded to sporulation stage. At salinities above $80 \mathrm{ppt}$, tomonts did not divide, but rather remained enclosed in a distinct capsule (fig. 4 Q). Division and sporulation occured in $25 \%$ or less of the tomonts when returned to optimal salinity within 12 days.

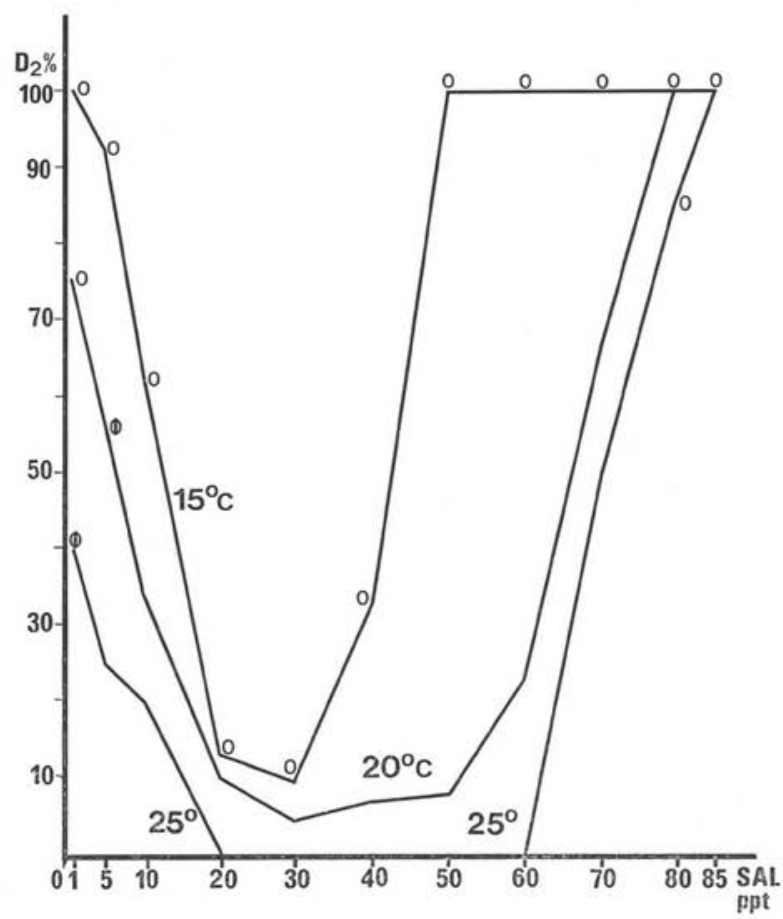

FIG. I2. - $\%$ of tomonts failing to divide beyond $2 \mathrm{~d}$ division ( $\mathrm{D}_{2} \%$ ) at different combinations of temperature and salinity. $\mathrm{O}-$ no sporulations at this combination of temperature and salinity. 


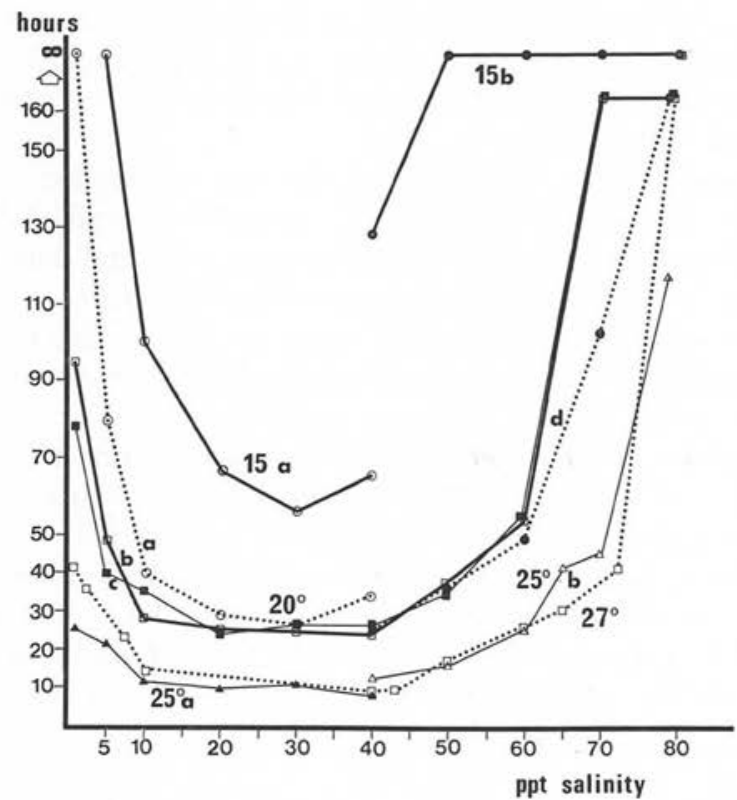

FIG. I3. - Mean time lapse between divisions at different combinations of temperature and salinities (a, b, c - parallel groups of same stock).

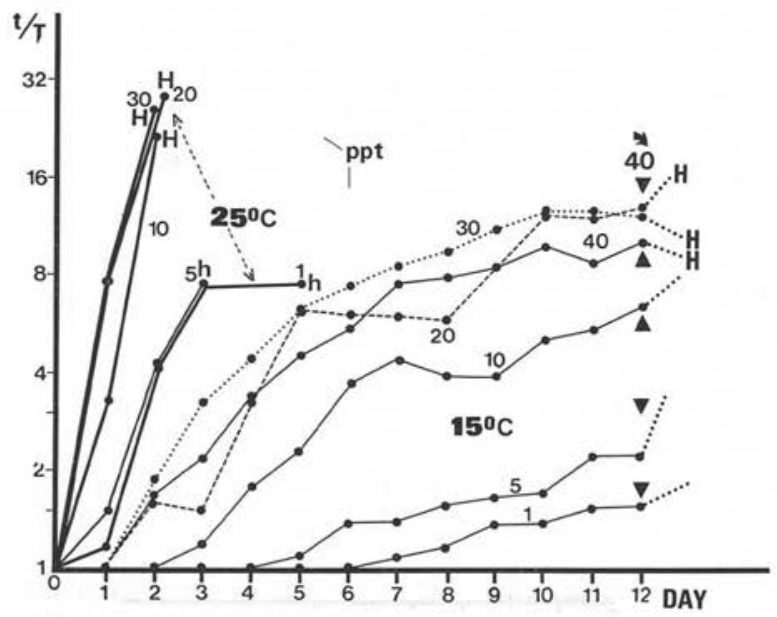

FIG. I4. - Combined effect of temperature $\left(15^{\circ} \mathrm{C}\right.$ and $\left.25^{\circ} \mathrm{C}\right)$ and salinity on tomonts division and sporulation $(\mathrm{H})(\mathrm{t} / \mathrm{T}$ - mean number tomites per tomont) - hyposaline range, arrowreturn to $40 \mathrm{ppt}, 20^{\circ} \mathrm{C}$. 


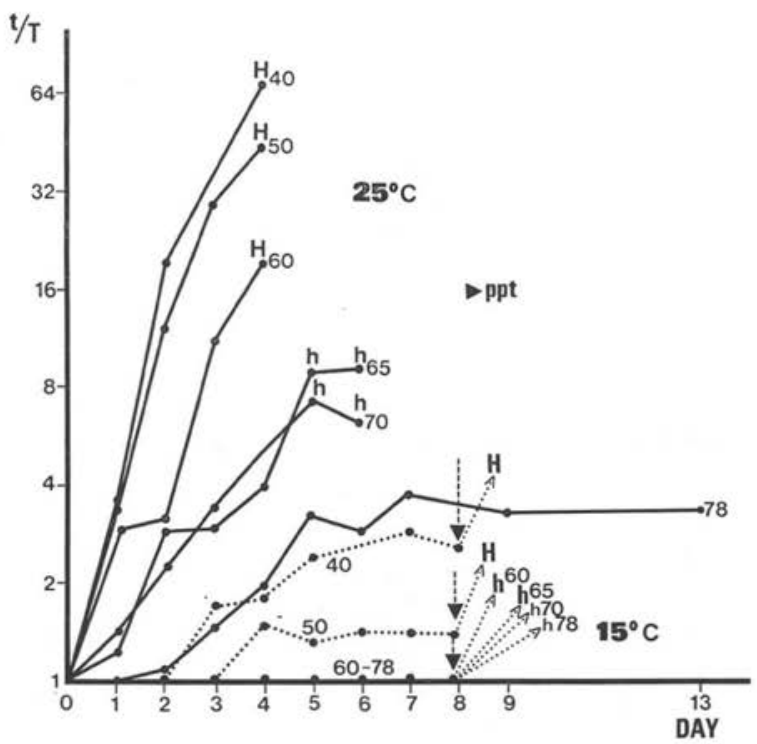

FIG. 15. - Combined effect of temperature $\left(15^{\circ} \mathrm{C}\right.$ and $\left.25^{\circ} \mathrm{C}\right)$ and salinity on tomont division and sporulation $(\mathrm{H})(\mathrm{t} / \mathrm{T}$ - mean number tomites per tomont) - hypersaline range, arrowreturn to $40 \mathrm{ppt}, 20^{\circ} \mathrm{C}$.

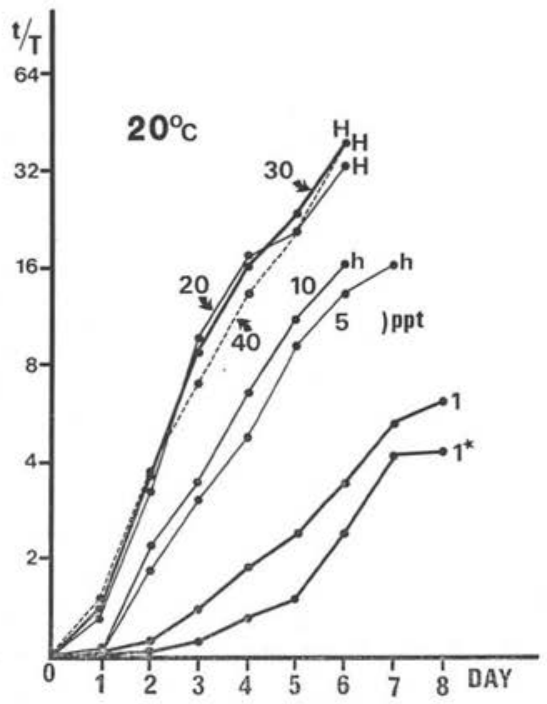

FIG. 16. - Effect of salinity on tomonts division incubated at $20^{\circ} \mathrm{C}$-hyposaline range $\left(^{*}-\right.$ different group). 


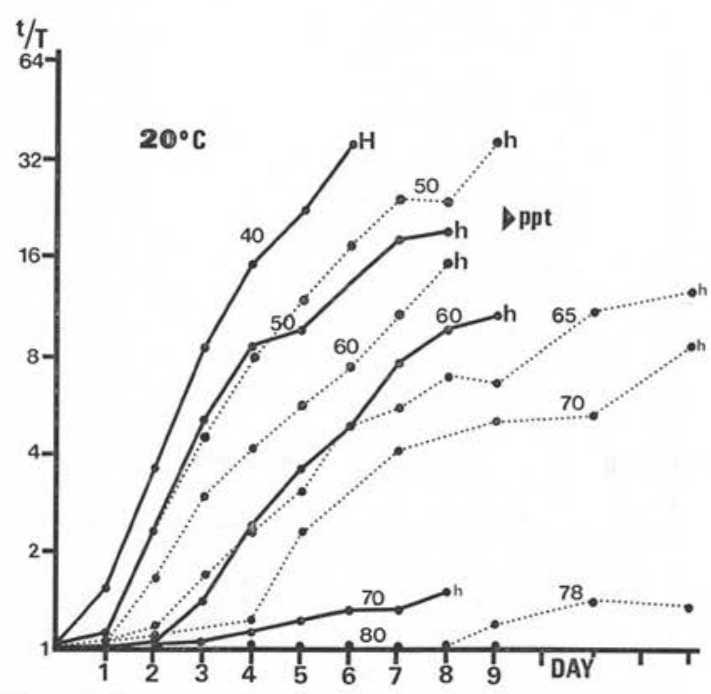

FIG. I7. - Effect of salinity on tomonts division incubated at $20^{\circ} \mathrm{C}$ - hypersaline range (dotted line - different group).

Division and sporulation of tomonts was resumed, if salinity, increased during the division process up to $160 \mathrm{ppt}$, was reduced to optimal level within 1-4 days. On return to optimal salinities recovery of dividing tomonts (at 3-5th division), was only partial (20-25\%) if exposed to $180 \mathrm{ppt}-200 \mathrm{ppt}$ for 1-4 days, while more prolonged exposure (over 5 days) to $160 \mathrm{ppt}-200 \mathrm{ppt}$ resulted in the death of the tomonts.

During incubation at $20^{\circ} \mathrm{C}$, functional and structural changes which evidenced adverse osmotic conditions already appeared at $10 \mathrm{ppt}$ and $60 \mathrm{ppt}$, while some decline in the yield of dinospores were apparent at $50 \mathrm{ppt}$. Tomonts incubated at $15^{\circ} \mathrm{C}$, at $10 \mathrm{ppt}$ demonstrated severe aberrations of divisions, more extreme than in those incubated at $20^{\circ} \mathrm{C}$. The adverse effect of hypersaline conditions at $15^{\circ} \mathrm{C}$ was already apparent at 50 ppt. Delay in onset of divisions - "lag phase", as salinities became more extreme was most evident at $15^{\circ} \mathrm{C}$ in the hypersaline range ; this delay becomes infinitive already at $60 \mathrm{ppt}$. In $20^{\circ} \mathrm{C}$, lag phase is evident only in salinities of $70 \mathrm{ppt}$ and over and below 2 ppt. Discrepancy from the synchrony in divisions among tomonts under extreme salinity conditions was more evident (yielding a coefficient of variation values of 90-160) at the hypohaline range, while at the hypersaline range it was evident only in tomonts incubated at $25^{\circ} \mathrm{C}$. With the overall decline in division activity, evident particularly at incubation in $15^{\circ} \mathrm{C}$, variability tended to dimunuate, reaching close to 0 value whenever division activity reached close to complete interruption (fig. 18).

Effect of salinities on tomont reproduction was tested in parallel in situ experiments with Sparus aurata postlarvae. No infection occurred in fish maintained at salinity below $12 \mathrm{ppt}$ and above $50 \mathrm{ppt}$. Results were controversial however, in two 


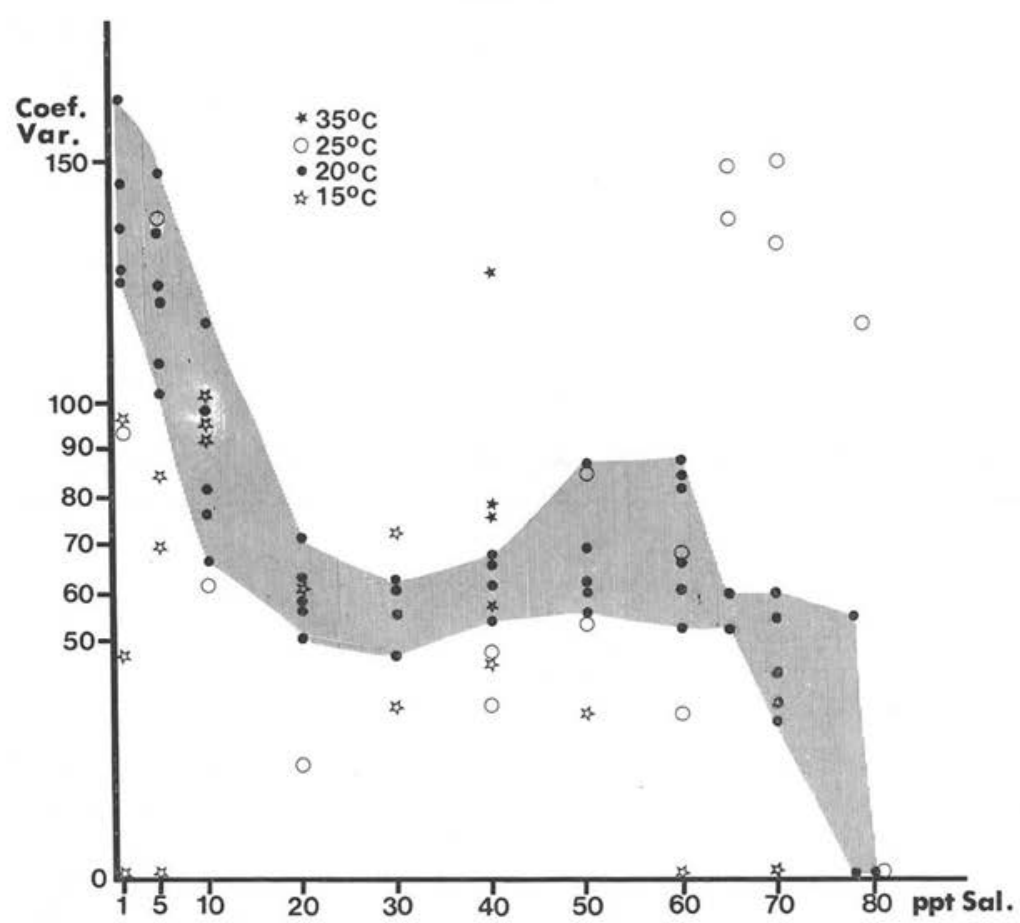

FIG. I8. - Coefficient of variability in sequence of division among groups of tomonts incubated at different combinations of temperature and salinities. Shaded area : range of variability at incubation at $20^{\circ} \mathrm{C}$ at variable salinities.

experiments carried out in the subsequent year, during which infections already were eliminated below $20 \mathrm{ppt}$ (Table IV).

One and a half hour incubation of dislodged trophonts in optimal salinity $(40 \mathrm{ppt}$ at $25^{\circ} \mathrm{C}$ ) before transfer to extreme salinities, e.g., allowing the trophonts to seal the rhizoid opening and encapsulate, was expected to improve tomit tolerance to extreme salinities. Results obtained at tested temperatures of $20^{\circ} \mathrm{C}$ did not evidence, however, any appreciable effect of this treatment on the tolerance of the tomites to extreme salinities.

\section{6 - The effect of drying on tomont survival}

All tomonts exposed to dehydration through sun drying as well as drying in $20^{\circ}$ and $35^{\circ} \mathrm{C}$ incubators failed to divide on return to optimal conditions of $40 \mathrm{ppt} /$ $20^{\circ} \mathrm{C}$. Drying after prior washing in tap water, to exclude salt concentration and crystallization during the drying process, did not alleviate the detrimental effect of drying on the vitality of the tomonts. 
TABLE IV. - Infection in postlarvae of Sparus aurata (number of parasites per fish), maintained at different salinities (temperature $19-24^{\circ} \mathrm{C}$ ).

\begin{tabular}{cccccccccc}
\hline & & \multicolumn{8}{c}{ Salinity (ppt) } \\
Year/date & 5 & 12 & 15 & 20 & 25 & 30 & 40 & 65 & 70 \\
\hline $1978 / 5.5^{*}$ & - & $18 \pm 31$ & - & $17 \pm 19$ & - & - & $30 \pm 36$ & - & - \\
$6.5^{*}$ & - & $51 \pm 55$ & - & $52 \pm 37$ & - & - & $60 \pm 66$ & - & - \\
$1980 / 6.4(\mathrm{I})$ & 0 & - & 0 & 3 & - & - & 54 & 0 & 0 \\
9.4 & 0 & - & 0 & 11 & - & - & $86-100$ & 0 & 0 \\
$1980 / 17.4(\mathrm{II})$ & 0 & - & 0 & 0 & 0 & $50+$ & $100+$ & - & - \\
18.5 & 0 & - & 0 & 0 & 0 & $300+$ & $500+$ & - & - \\
\hline
\end{tabular}

* t-test : non-significant

\section{Discussion}

There is apparently no defined stage of maturity in $A$. ocellatum at which parasitic forms cease growing and transform into the non-parasitic dividing stage. This was evident from continuous, uninterrupted linear growth pattern of the trophonts up to the stage of detachment, and from the ability of the trophonts to transform into dividing tomonts upon dislodgement, irrespective of age or size. The latter phenomenon was already noted by Brown (1934), Nigrelli (1936) and Brown \& Hovasse (1945) and also occurs according to Jacobs (1946) in Oodinium limneticus. In O. limneticus however, growth data as presented by Jacobs (1946) suggested interruption (or slowdown) in growth (for one week) prior to detachment.

Thus, it appears that detachment in A. ocellatum is not voluntary following maturation but occurs as a consequence of the increasing incompatability of the parasite to maintain its attachment on the host tissue substrate. This is due either to the increase in size of the parasite which apparently amplifies the magnitude of friction with the water current over the integumental surface (skin and gills), and/or due to the decline in its attachment efficiency through rhizoids when the host tissue substrate gradually turns necrotic or hyperplastic. These changes in the host tissue at the parasite's attachment site have been demonstrated in both histopathological (Paperna, 1980) and ultrastructural studies (Lom and Lawler, 1973). At low temperature, when fish activity is slowed down, the process of detachment was delayed (from 4-5 to 7 days) and consequently tomonts also attained larger sizes (over $100 \mu \mathrm{m}$ compared to an average of $80-90 \mu \mathrm{m}$ at $20-25^{\circ} \mathrm{C}$ ).

There is a difference in opinion between Brown (1934) and Nigrelli (1936) about whether the size of the trophont at detachment or incubation conditions determine the ultimate number of divisions prior to sporulation. Present studies have shown that the potential number of divisions to sporulation as suggested by Brown is deter- 
mined by the initial size of the tomont, however, the incubation conditions will determine whether tomonts whill divide to their maximal potential capacity as implied from their size at detachment before sporulation. Tomonts seemed to yield their upmost potential number of divisions at the lower limit of the optimum temperature range $\left(18^{\circ} \mathrm{C}\right)$, the number of divisions was declining as the temperature increased toward the upper limit of the optimum range $\left(30^{\circ} \mathrm{C}\right)$. Higher division numbers were also observed in $30 \mathrm{ppt}$ than in $40 \mathrm{ppt}$ during incubation. As incubation conditions deviated from the optimal range (temperature and salinity), the number of divisions to sporulation further declined. Differences in the number of divisions to sporulation observed by Brown $(1931,1934)$ and Nigrelli (1936) and in the presently studied populations ( 7 vs. 5.6) may be therefore attributed both to the difference in overall size of the parasite at detachment (about $100 \mu \mathrm{m}$ vs. $80-90 \mu \mathrm{m}$ ) as well as to differences in incubation techniques.

Trophonts, younger than 24 hours or smaller than $30 \mu \mathrm{m}$, if dislodged, did not divide but rather immediately sporulated and yielded twin mobile dinospores. This process has been overlooked by the earlier workers (Brown and Nigrelli) but has been reported to occur in O. limneticus by Jacobs (1945).

There is a synergistic effect of temperature and salinity over the tolerance of the dividing tomont. Tolerance to salinity narrowed as temperature diverged from its optimal range. Results of present studies on tomont tolerance to temperatures and salinities confirm in general with the previous data of Brown (1934), Nigrelli (1936) and Cheung et al. (1978). The brief presentation of such data and lack of quantitative accounts in the above cited works make attempted comparison and evaluation of discrepancies between present and previously published data irrelevant.

Effective reproduction of tomonts was limited within a temperature range of $16-30^{\circ} \mathrm{C}$ and salinities of $12 \mathrm{ppt}$ to $50 \mathrm{ppt}$. Beyond these ranges division occured and some dinospores were produced, but yielded dinospores were non-mobile or defective and apparently their infective ability was declining or lost. Infection experiments of fishes at these ambient conditions confirmed this assumption. Differences in results on tolerance of $A$. ocellatum to salinity obtained in the years 1978 and 1980 suggest however the existence of populations with different ranges of tolerance to salinity (and possible also to temperature). Furthermore, distinct variability could also be demonstrated in the tolerance to extreme conditions along individual tomonts. Differences in tolerance to extreme conditions could be partly attributed to size differences. Nevertheless even among tomonts of equal size, this individual variability was distinct. Even individual offspring tomites within each tomont varied in their susceptibility to extreme conditions. It is yet to be determined whether this variability is of a genetic origin or a result of random structural and functional variations inherent in the population. The observed variability may have important faunistic and epizootic implications : If this variability in A. ocellatum populations is a result of genetic heterogenicity, it consequently could yield to selective pressure with resulting venues for potential introduction and acclimitization into new habitats, and aquaculture systems in particular, so far free from this parasite. A recent report of 
Ghittino et al. (1980) of an outbreak of infection of Dicentrarchus labrax in a brackish water culture system (20-30\%) in north Italy and findings of infection in maricultured fish in Séte, France (at $18^{\circ} \mathrm{C}$ ambient temperature, Paperna et al., 1979) may evident such process.

Acknowledgements. This research was supported by a grant from the GKSS Geesthacht Tepershude, Federal Republic of Germany.

I wish to acknowledge the important assistance and scientific contribution of Mr. Brian Ross to this research. I wish he could also have participated in the writing of this paper but he chose to explore the mysteries of the Himalayas.

\section{REFERENCES}

Brown E. M. : Note on a new species of Dinoflagellate from the gills and epidermis of marine fishes. Proc. Zool. Soc. London, I931, Part I, 345-366.

Brown E. M. : On Oodinium ocellatum Brown, a parasitic dinoflagellate causing epidemic disease in marine fish. Proc. Soc. London, 1934, Part 3, 583-607.

Brown E. M., Hovasse R. : Amyloodinium ocellatum (Brown), a peridinian parasitic on marine fishes. Proc. Zool. Soc. London, 1946, 116, 33-46.

Cheung P. J., Ruggieri P. F., Nigrelli R. F. : Effect of temperature and salinity on the development cycle of Oodinium ocellatum Brown (Mastogophora : Phytomastogophorea, Dinoflagellidea). IV Int. Cong. Parasit. Warszawa, I936, Sec. A, 25.

Ghittino P., Bignami S., Annibali A., Boni L. : Prima segnalazione di grave Oodiniasi in branzini (Dicentrarchus labrax) allevati intensivamente in acqua salmastra. Riv. It. Piscic. Ittiop, I980, Is, 122-127.

Jacobs D. L. : A new parasitic Dinoflagellate from fresh-water fish. Trans. Am. Mic. Soc., r946, $L X V, I-17$.

LOM J., LAwLER A. R. : An ultrastructural study on the mode of attachment in dinoflagellates invading gills of Cyprinodontidae. Protistologica, 1973, 9, 293-309.

Nigrelli R. F. : The morphology, cytology and life-history of Oodinium ocellatum Brown, a Dinoflagellate parasitic on marine fishes. Zoologica, 1936, 2I, 129-164.

PAPERna I., Baudin-Laurencin F. : Parasitic infections of seabass, Dicentrarchus labrax and gilthead seabream Sparus aurata in mariculture facilities in France. Aquaculture, 1979, 16, I 73-I 75 .

PAPERNA I.: Amyloodinium ocellatum (Brown, I93I) (Dinoflagellida) infestation in cultured marine fish at Eilat, Red Sea : Epizootiology and pathology. J. Fish Diseases, 1980, 3, 363-372. 